Higgins, M., \& Kim, E.J. (in press). De/colonizing methodologies in science education: Rebraiding research theory-practiceethics with Indigenous theories and theorists. Cultural Studies of Science Education.

\title{
De/colonizing methodologies in science education: Rebraiding research theory-practice-ethics with Indigenous theories and theorists
}

\author{
Marc Higgins \\ Eun-Ji Amy Kim
}

\begin{abstract}
The purpose of this article is to differentially engage in the work of thinking with Indigenous theorists and theories with decolonizing science education research methodologies in mind. As a rejoinder to Tracey McMahon, Emily Griese, and DenYelle Baete Kenyon's Cultivating Native American scientists: An application of an Indigenous model to an undergraduate research experience, we extend the notion of educationally centering Indigenous processes, pedagogies, and protocols by considering methodology a site in which (neo-)colonial logics often linger. We suggest that (re)designing methodology with Indigenous theorists and theories is an important act of resistance, refusal, and resignification; we demonstrate this significance through braiding together narratives of our engagement in this task and provide insights as to what is produced or producible.
\end{abstract}

Keywords: decolonizing science education · decolonizing research methodologies · thinking with theory $\cdot$ relationality $\cdot$ research design

The study of research methodology in the current political and social context is not free from the influence of western disciplines of knowledge that have defined what counts as research within academic institutions, science organizations, publishers, funding bodies and the media. The knowledge economy, knowledge society, and policy links between knowledge and wealth creation are powerful political drivers for how different forms of knowledge production are viewed, supported, rewarded and legitimated and conversely how other forms are not supported. (Smith, Maxwell, Puke, \& Temara 2016, p. 141)

As Ngāti Kahungunu ki Wairarapa and Ngāi Tahu scholar Liz McKinley and Maori scholar Georgina Stewart (2012) state, "the aspiration of defining and understanding IK [Indigenous knowledges] (in order to place it in the science curriculum) can be likened to chasing the pot of gold at the end of the rainbow, which remains permanently out of reach" (p. 551). To include Indigenous science (e.g., Cajete 2000) or Indigenous ways-of-living-with-Nature (IWLN; e.g., Aikenhead and Michell 2011) within science education curriculum continues to be a complex and complicated process. Entangled within this is, inevitably, (neo-)colonial logics and enactments that support and naturalize the ways in which Indigenous ways-of-knowing-in-being continue to be under-or non-represented (even when it is included through appropriation) as well as under-valued within spaces of science education (Bang and Marin 2015). McKinley and Stewart (2012) posit that this marginalization results from attempts to fit Indigenous ways-of-knowing-in-being into Western scientific knowledge frameworks; for example, fitting Indigenous relational ontologies into a Cartesian ontology (e.g., Higgins in press). It must also be stated that these attempts cannot be separated from both colonial and neo-colonial desires and Lead Editor: M. Kim

This is a rejoinder to Tracey McMahon, Emily Griese, and DenYelle Baete Kenyon's "Cultivating Native American scientists: An application of an Indigenous model to an undergraduate research experience."

Corresponding author: Marc Higgins

University of Alberta, Department of Secondary Education

e-mail: marc.higgins@ualberta.ca 
discursive structures that require such a fit to be considered valid and valuable. While coloniality and neo-coloniality are often framed as historically distinct (i.e., past and present), these respective projects of territorial and economic imperialism are bound by a relation of co-constitutive exclusion (Spivak 1999). We signal this assumption through the use of the term (neo-)colonial throughout.

Within Indigenous ways-of-knowing-in-being, knowledge is inseparable from the relationships with/in the place from which it emerges. There is rich possibility and promise in not only thinking with Indigenous knowledge but also the processes through which they emerge. As Tracey McMahon, Emily Griese, and DenYelle Baete Kenyon's Cultivating Native American scientists: An application of an Indigenous model to an undergraduate research experience makes explicit, thinking with Indigenous models of pedagogy provides a rich and relational space from which to engage in making space for and nurturing diverse ways-of-knowing-in-being. Extending the authors' work of educationally centering Indigenous processes, pedagogies, and protocols through their use of the Circle of Courage, we turn our gaze to another process and practice in which (neo-)colonial logics often come to linger and in which thinking and doing with Indigenous theory-practices is an important act of resistance, refusal, and resignification. Particularly, we pivot towards research methodology.

As Maori scholar Linda Tuhiwai Smith (1999) states in Decolonizing Methodologies, "research is probably one of the dirtiest words in the Indigenous world's vocabulary" (p. 5). We interpret this as a gesture towards the long, pervasive, and widespread history of research that has lead to the appropriation and commodification of Indigenous knowledges and practices, the mis- and missed representations of Indigenous peoples that produce and uphold pathologizing images; in short, unethical research that has been conducted on rather than with participants (see also Tuck 2009). Highlighting these most egregious and explicit examples of research is of import generally and also of significance within spaces of science education specifically given that Western modern science's (WMS) problematic relation to Indigenous peoples, practices, and places continues to this day (e.g., Indigeneity, blood quantum, and genetics; see TallBear 2013). We posit that it is productive for researchers to shift attention from the ends of research to its means: methodology. As Smith and colleagues (2016) state, "in its simplest form, methodology explains the pathways between knowledge creation and knowledge production - the formation of knowledge." (p. 140). In making this transition from the ends to the means, they highlight the ways in which the disciplines discipline what counts as knowledge and, more to the point, focus on knowledge production processes to attend to the ways in which (neo-)coloniality manifests in much more subtle and implicit ways. Stated otherwise, colonial logics, flows, and forces may come to shape what is produced in and through research if we do not attend to the ways in which our processes come to reify the (neo-)colonial categories, concepts, and structures even as we labour against them. In this way, decolonizing becomes de/colonizing. $\mathrm{De} /$ colonizing signals the ways in which decolonizing cannot be wholly framed in opposition to colonization, at least not within academic and other formal educational spaces given the complexity of their material-discursive structures, even if and when they pursue decolonizing goals (e.g., Nakata 2007). As Lemke (2011) points towards the conservative nature of the field, de/colonizing is to be taken seriously: perhaps a decolonizing imaginary that is simultaneously also intelligible as science education, even within its margins and alternative spaces, might continue to be an impossibility (see Sammel 2009). Thus, to take seriously de/colonizing is to be hyper-vigilant of the ways in which (neo)colonial logics and productions seep into decolonizing efforts. Methodologically, it is to respond to and be response-able throughout research processes to the striking question asked by Smith and colleagues (2016): “are methodologies simply new technologies of cultural assimilation?" (p. 133).

Part of the complication around methodology is the (neo-)colonial logics of separation and separability that often frame research design as pre-existing the empirical work of the practice of 
research (e.g., field work, analysis, writing, dissemination). As Smith (1999) states, such an enactment of distance (via separation and seperability) cannot be separated from the "specific spatial vocabulary of colonialism which can be assembled around three concepts: (1) the line, (2) the centre, and (3) the outside" (Smith 1999, p. 55). Not only do these three concepts that are almost always at play in (neo)colonial logics produce notions of hierarchy through proposing a center and a margin, the drawing of the line between them signals an oppositional difference. In science education, we often see these logics at play when the case for WMS' centrality is (increasingly implicitly) made: it is heralded as the way of knowing nature because it is framed as not being the orientations that it is defined against, such as IWLN. This is further complicated by the ways in which (neo-)colonial logics simultaneously desire "to make the ends coincide with the means" (Spivak 1976, p. xx). Stated otherwise, while the practices of research are almost always inevitably separated from the products of research, knowledge claims often suture over the relations and processes irreducibly enfolded within them through the desire to make them one and the same. This double(d) process comes to mask the ways in which methodology is always already a co-constitutive space of theory, practice, and ethics; requiring either that it be wholly different or collapsed into sameness (see Higgins, Madden, Bérard, Lenz Kothe, and Nordstrom 2017). This is one of the significant ways in which which (neo-)colonial referents (both theoretical and conceptual) often continue to linger and lurk within the processes of generating knowledge in science education.

Resisting, refusing, and redirecting the ways in which (neo-)colonial logics circulate invites consideration of methodology as an object of study and as a site of struggle. In line with decolonizing and post-colonial science education scholars who articulate that theory too is a practice and that practice is always already theoretical (e.g., Carter 2005; McKinley and Aikenhead 2005), we turn to methodology as a site that is at once problematic yet also productive. In this task, we draw inspiration from the work of Alicia Jackson and Lisa Mazzei (2012) who, in their data analysis practice, "think with theory" in ways that disrupt and displace taken-for-granted ways-of-knowing-in-being. We consider "thinking with theory" a useful form of engagement that can be put to work across all stages of research, from the design to the dissemination (see Higgins et al. 2017). We hold that because methodology only exists with/in contingent and situated relations, it is always already open to being re-worked, re-thought, and differentially enacted. Here, specifically, we work within, against, and beyond the ways in which (neo-)colonial logics remain in "pre-existing" methodologies by thinking with the work of Indigenous scholars, Elders, and knowledge holders.

As an important note, such knowledge includes but is not limited to Indigenous traditional knowledge practices (which, importantly, continue to be relevant today through their perpetual relational reworking; see Cajete 2000). Also, it includes knowledge of and through colonialism: Indigenous knowledge includes knowledge of imperialism from the West, the East or even from the neighbours, deep knowledge of colonizers and the practices and effects of colonization, of different religions that were imposed, of nation states formed by different conceptions of a state, western democratic, socialist or communist, and of the institutions of the state (Smith et al. 2016, p. 136)

Representationally, we draw insight from Papaschase Cree scholar Dwayne Donald's (2012) Indigenous Métissage. Indigenous Métissage is "a research sensibility that is against prescribed method" (p. 544) whose central aim is "to reconstruct understandings of the [(neo-)]colonial constructs people (including the researcher) hold" (p. 545) and by which they are held. This is done through the braiding and purposeful juxtaposition of differential narratives engaging with/in Indigenous-nonIndigenous relationalities. Herein, we work to braid together our situated and partial narratives of thinking with Indigenous scholars, Elders, and knowledge holders. We work to give an account, recognizing the impossibility of giving the account. 
These accounts of our respective methodological work are presented in four distinct threads. The first strand identifies the Indigenous theorist(s) with whom we respectively think with as well as the theory or concept that assists us in de/colonizing research methodologies in science education. The second strand identifies the specific locations in and from which we are re-weaving its theory-practiceethics with guidance from experiences of learning with, from, and alongside Indigenous scholars, Elders, and knowledge holders. The third strand of the braid engages with the work of braiding in and with Indigenous thought. The fourth and final braid glances back at what was produced or producible within such a de/colonizing rebraiding, as well as looks ahead to how we might carry the braid forward in a good way.

\section{Thread 1: Thinking with Indigenous theorists and theories: Gathering the threads from where we are} situated

\section{Marc Higgins - Thinking with Ahenakew's metaphor of grafting}

As Plains Cree scholar Cash Ahenakew (2017) states, "the work of decolonization is not about what we do not imagine, but what we cannot imagine from our Western ways of knowing" (p. 88). As a white, male, fourth generation Canadian Euro-settler of Irish and Scottish descent who is working towards being and becoming an ally to honour my ever-shifting relationships as a science educator working with/in diverse First Nations, Métis, and Inuit communities, I recognize that there are things that I cannot know. Yet, as I continue labouring spaces of science education, I occasionally catch sideways glimpses of myself engaging in the (neo-)colonial desiring of cultural diversity without epistemological diversity (see Higgins 2014a). Stated otherwise: I employ(ed) a form of epistemic ignorance in which I assume that other cultural knowledges map onto mine (e.g., logics of commensurability; see Andreotti, Ahenakew, Cooper 2011). Epistemic ignorance is both mine and simultaneously not; I continue to grapple with the ways I am at once discursively produced by and (re)producing epistemic ignorance in science education.

However, addressing epistemic ignorance is not simply a process of acquiring more knowledge: it is both addressing what we do not know but also what prevents us from knowing otherwise. This signals knowledge-as-ignorance, rather than a lack of knowledge. As mentioned earlier, this greatly comes to matter in both science education and educational research landscapes as they shift from questions of inclusion and exclusion towards complicating the ways in which Indigenous ways-ofknowing-in-being are included and juxtaposed next to Western ones. There is need to be hyper-vigilant of the ways in which the former logics of exclusion shape the ways in which inclusion occurs. For example, Ahenakew (2017) argues that Indigenous ways-of-knowing-in-being are often included in utilitarian ways such that they are at the service of knowledge presented as "universal," as a tokenistic means to an end which "is a move to distract from more unsettling Indigenous demands for decolonization" (p. 85). Further, there is a necessity to attend to the ways in which the field of science education discursively renders unintelligible those facets of Indigenous ways-of-knowing-in-being that do not fit within a Western modern episteme (McKinley and Stewart 2012).

Herein, I turn to work of Cash Ahenakew to engage with these forms of knowledge-asignorance in the process of looking back at previous research and think forward about research tocome. Particularly, I turn to his use of the metaphor of grafting to re(con)figure the ways these uneven and unequal relations play out:

Grafting is used in biology as the process of transplanting something from one organism into another (e.g., hybrid plants or cell/skin implants). Grafting, in itself, is neither good nor bad. Indeed, hybridity can be a generative process. However, in the context of grafting Indigenous knowledges into non-Indigenous 
ways of knowing, we are operating with severely uneven environments shaped by historical circumstances where the grafting/hybridizing does not happen as a mutual exercise, but as assimilation. Grafting, in this sense, can further contribute to the elimination of Indigenous peoples as distinct Indigenous peoples both in their relationship with the state, in their relation to the land, and in terms of the perceived worth of their knowledge. (Ahenakew 2016, p. 325)

While not dismissing the importance of finding ways of relating Indigenous and Western ways-ofknowing-in-being through complementarity rather than contradiction, Ahenakew (2016) reminds that "very seldom we ask what is lost in translations between global/cosmopolitan and Indigenous/local knowledges" (p. 329). What would it mean to engage in a less innocent cross-cultural methodological design that accounted for and was accountable to what is lost through grafting in science education?

\section{Amy Kim - Thinking with Relationships and Decolonization}

My name is Eun-Ji Amy Kim. I am part of the 71st generation of the Sam-hyun tribe (삼현 파) of Kimhae (김해), Korea. I was born in Seoul, Korea. When I was 16 years old, my family moved to Winnipeg, Canada, the territory of the Anishinaabeg, Cree, Oji-Cree, Dakota, and Dene peoples; this is also the territory of the Métis and Treaty 1 Territory. I currently reside, do research, and teach in Montreal, Canada, the unceded territory of the Kanien'kehá:ka (Mohawk) people, known as Tiotia:ke in their language (Canadian Association of University Teachers 2016). I consider myself to be in an individual who is in the process of learning from and becoming an ally to Indigenous peoples (Bishop 2015).

The notion of 'relationship' plays a pivotal role in my life, from carrying out a research project to understanding and making sense of the world around me. Building and reflecting on relationships, especially between IKS and WMS in the context of science education, and Indigenous and Western research frameworks has been a major part for my research project. Cree scholar Shawn Wilson (2008) states, "concepts or ideas are not as important as the relationships that went into forming them" (p. 74). French scholar, Michel Foucault (1982), was also interested in exploring relationship as he introduced his idea of "power as relations": that power is exercised rather than possessed. Thus, one should look into the ways in which power is exercised through different relations. Acknowledging the importance of focusing on relations/relationships, my research asks, 'What relationships are at play in integrating Indigenous perspectives in school science?' I was drawn to Fairclough's three-tiered model (1992) as it gives a specific framework to conceptualize and analyze different relations involved in integrating Indigenous knowledges in science curricula.

Norman Fairclough was a social linguist (1989) from Britain who suggested that in analyzing educational policies and documents such as official curricula, one must consider the "relationships between texts, processes, and their social conditions, both the immediate conditions of the situational context and the more remote conditions of institutional and social structures" (p. 26). In this light, Fairclough (1992) put forth a three-tiered model, which includes both text and social practice (Figure 1). 


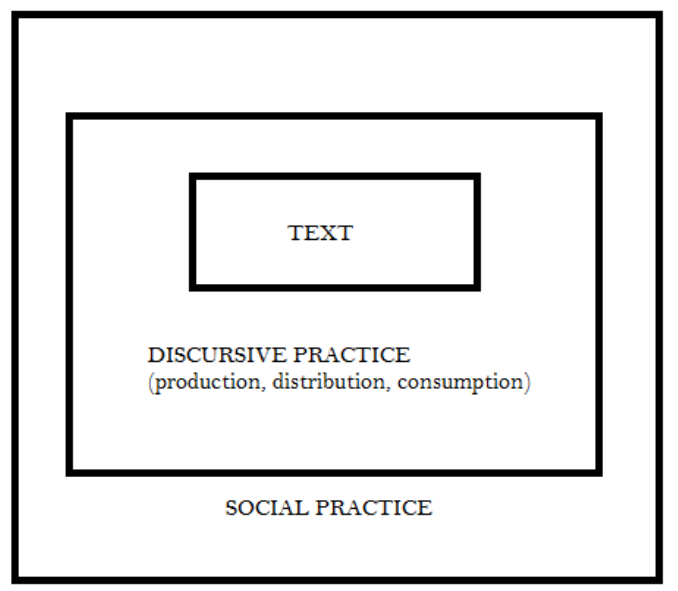

Figure 1. Three-tiered conception of discourse (reproduced from Fairclough1992, p. 73).

Fairclough's three-tiered model offered a specific framework for me to conceptualize the different relationships involved in 'curriculum document' production. Fairclough's three-tiered model thus has guided me from an earlier phase of the project, of selecting what types of data I should invite into my research, to the analysis and writing process. While Fairclough's model permitted me to conceptualize and explore different relations involved in curriculum documents' production with a larger social context, it did not include me, as a researcher. As Wilson (2008) reminded, "research is ceremony. The purpose of any ceremony is to build stronger relationships or bridge the distance between aspects of our cosmos and ourselves" (p. 11). Indeed, in my research, I have experienced being part of building relationships between different ideas and stories and theories.

In thinking about the relations between different data sources for each tier, I was given advice from Cree scholar Dr. Laara Fitznor that as an ally researcher, I should make my own meaning and interpretations of various multiple ways of doing research that are driven by the relationships I have with people and the land. However, in so doing, I should remain committed to decolonization. Dr. Fitznor defined decolonization as:

"Decolonization means willingness to see and look back to history behind. Everyone needs to be decolonized. Not only Indigenous peoples. In engaging with decolonizing activity, asking questions such as "Where is power dynamics? What do/ encourage through this activity?" - are important. Also, decolonizing activity involves supporting Indigenous sovereignty, including Indigenous feminist sovereignty. (Personal communication, March 26, 2016, emphasis added).

\section{Thread 2: Methodological strands into and with which we braid}

\section{Marc Higgins - Looking back: Grafting in de/colonizing science education}

As Ahenakew (2016) states, "it is indispensable to take an honest look at the problems of inclusion without the need for excuses, appeasement, or angry accusations" (Ahenakew, 2016, p. 329). As I look back at my own engagement in de/colonizing methodologies, I have sought multiple ways to bring Indigenous and Western ways-of-knowing-in-being into relation (while simultaneously refusing common tropes of commensurability and incommensurability which often come to leave researchers "off the hook"). One significant example of this type of work is the substitutive grafting of Torres Islander scholar Martin Nakata's (2007) Indigenous standpoint theory and Quechua scholar Sandy Grande's (2008) Indigenous praxis to reconstitute photovoice through differentially articulating its central theories of standpoint theory and praxis (see Higgins 2014b). Yet, Ahenakew's (2016) concept of grafting invites me to rethink how I approach the very possibility of braiding together these 
paradigms with decolonizing goals in mind, without abandoning the project as the "objective [is] not to discourage people from taking up Indigenous methodologies but to encourage us all to do so with critical eyes wide open in relation to the agendas of institutions and to our own imperfect translations" (p. 337).

As I revisit my labour of de/colonizing methodologies, my first encounter of "the paradoxes and limitations of translating insights between Indigenous and non-Indigenous spaces" (Ahenakew 2016, p. 337) methodologically was in my attempt to have Indigenous and non-Indigenous youth visually document the multiple modes through which ways-of-knowing-Nature (science in the broadest sense of the definition) were being enacted in their community of Iqaluit, Nunavut (in the Canadian Arctic; see Higgins 2014a). While this made space for a multiplicity of cultural meanings there were nonetheless things I could not grasp; notably the ways in which cultural meanings extended into epistemological spaces beyond those through which I conceptualized what and how Nature was knowable. I struggled to recognize the ways in which youth were constructing knowledge of Nature that was not strictly about Nature but instead with it. As I have explored elsewhere, this epistemic blindness cannot be disassociated from the metaphysics of modernity through which ontology and epistemology, nature and culture, are kept separate and separable (Higgins 2017a). As Ahenakew and colleagues state, these metaphysics:

work more like a grammar that systematically structures what can and cannot be said, hiding their choices about what is real, normal and good, and presenting its sentences as objective, natural and transparent. (Ahenakew, Andreotti, Cooper, Hireme 2014, p. 217)

Here, the presupposition that ontology precedes epistemology (so that all knowledge claims map onto the same ontological reality) would act as a form of knowledge-as-ignorance. This would result in an enactment of "a kind of grafting that seems to maintain primary loyalty to accepted notions of time, progress, reality, and being" (Ahenakew 2016, p. 333).

While the ways-of-knowing-in-being that the youth were orienting me towards is represented here as but a subtle linguistic shift (i.e., between about and with), the consequences for knowing, being, and ethics are substantial. But they are also "ontological and metaphysical claims of an unnarrativizable reality not articulable by the Cartesian subject" (Ahenakew, Andreotti, Cooper, \& Hireme, 2014 p. 218).

Thus, the question for Ahenakew (2017), and it is one that is both "deceivingly simple" and of import for science education is the following: "How can we (re)learn to listen to and be taught by the land, in the context of ongoing efforts to objectify, to commodify, to silence, or to speak for the land?" (Ahenakew, 2017 p. 81)

\section{Amy Kim - Guiding braiding principles: Nisitohtamowin and Kemochly}

Cree scholar Dr. Margaret Kovach (2009) introduced the Cree word Nisitohtamowin (understanding) in the context of research, whose meaning is in line with what Dr. Fyre Jean Graveline, a Métis (Cree) scholar, (1998) speaks of as "self-in-relation" (p. 52). It is the idea that I, myself am related with all living things in this cosmos. Tewa scholar Gregory Cajete (2000) also shared the same view of sacred ecology: we are all related. It is through this notion of Nisitohtamowin -"self-in-relation" (Graveline, 1998 p. 52) - that I discovered for myself the relationship between theories, data, ethics, land, peoples and myself. Nisitohtamowin encourages respect, reflexivity, integrity, and relationships with others and helps create new forms of understanding. Nisitohtamowin- understanding of self-in-relation- was guiding me to grapple with, think about, and reflect upon the possibility of making my own 
interpretations and new meanings arising from braiding Indigenous thoughts, along with Fairclough's model for my doctoral research project.

Meanwhile, the notion of Kemochly also guided my research process. It was a "Cree-ish" word taught by Dr. Fitznor. It means "in secret" and "working against" (Personal communication, March 26, 2016). Kemoch is a Cree word and 'ly' was added to make its ending consistent with an English adverb.

One afternoon, over lunch at Altos in Winnipeg, I spoke to Dr. Fitznor about my questions and dilemma regarding to what extent I could draw from Indigenous and/or Western frameworks for this project. Instead of giving me a direct answer, she taught me the word, Kemochly. She suggested that I should find my own "living set of parameters" (Personal communication, March 26, 2016). Life is a continual process of coming to know and it is from my living inquiry that learning comes, "Kemochlyin secret." Through living inquiry, I have come to understand what my own interpretation of the world is (Wilson 2008). Finding my own living set of parameters is important in this process of Kemochly. For the question: To what extent can I draw from Indigenous and Western frameworks? I realize that the answer can be found within myself- it comes from my own living inquiry and my own integrity. Dr. Fitznor also advised, "whatever choices you make, you need to feel comfortable about them" (Personal communication, March 26, 2016). I attempt to "work against (Kemochly)" the dominant, internalized ideas that come from the Western world in which I currently reside. As Kovach (2009) mentioned, "the most effective allies are those who are able to respect Indigenous research frameworks on their own terms. This involves a responsibility to know what that means" (p. 13). For me, this was about being grounded. Being grounded involves knowing my politics of truth (Kovach 2009), knowing where I am from in relation to my ancestors and being aware of my position as a person who is becoming an ally, rather than an Indigenous person or an expert in Indigenous issues. It maintains my integrity within the project, and demonstrates that I have made a commitment to learn through this process.

With Nisitohtamowin and Kemochly, I was able to think about my relationship with different discursive and social relations that are involved in integrating Indigenous knowledges-sciences in school science in my research context. This allows continual reflection on my relations to data, theories and ethics throughout the research project. Also, it was the understandings and lessons that came with these two words that allowed me to re-braid stories and lessons I received from Indigenous Elders and scholars and my lived experience with Fairclough's model.

\section{Thread 3: (Re)Braiding methodology}

\section{Marc Higgins - Braiding in the recent present: Attempting to make the invisible visible}

Grappling with the question of "how we might (re)learn to listen to and be taught by the land" (Ahenakew 2017, p. 81), during the subsequent science education research project I designed and carried out I attempted to make visible that which was absent yet present. In attempting to make space for the ways in which knowing, being, and ethics are not only interdependent but coconstitutive, I opted to re(con)figure my former approach of visually narrating ways-of-knowing-Nature by beginning from a location from which there might be room to recognize that:

\footnotetext{
...the land is ontologically alive: it is breathing, breeding, dreaming, kicking, sweating, cursing, morphing, laughing, crying, dancing, drumming, singing, eating, burping, farting, shitting, decaying, dying, and being born again. It does not fit notions of linear ticking rushing time. It is cognitively incomprehensible and metaphysically mysterious, but sensually accessible as an extension of our bodies, except when we are contained in a box of ontological concrete. (Ahenakew 2017, p. 81)
}

Toward this end, I would braid together Tewa scholar Gregory Cajete's (1994) "ecology of 
relationships" with Karen Barad's (2000) "agential literacy" into my methodological theory-practice to attempt to account for and be accountable to the ways in which other-than-humans come-to-matter (in both senses of the word - mattering as meaningfulness and materialization) in meaning-making with Nature (e.g., Higgins 2016). Barad's (2000) quantum philosophy-physics seemed to offer a different ontological point of departure from which to begin; one in which commensurability seemed greater due to its similar yet different post-Cartesian accounting for ethico-onto-epistemologies in which other-than-humans are agentic and teachers.

This responded to "the challenge of introducing newness in terms that are intelligible and familiar to the dominant research ontology" (Ahenakew 2016, p. 333) by offering Barad's work as an (un)familiar pivot towards Indigeneity: being at once situated within Western modern science (e.g., drawing heavily on Niels Bohr's work) but offering a radically queer way-of-knowing-Nature. This approach yielded some successes (e.g., youth's enactments with agentic other-than-humans and nonlinear spacetimes), as well as productive new ways of failing.

Yet, revisiting this work with Ahenakew (2016) invites a consideration of the ways in which success "becomes a problem when we cannot recognize what is lost in translation" (Ahenakew, 2016, p. 333). As Ahenakew cautions, when we wholly refuse modernity through dialectic negation (and the hubris and teleology of progress in which we believe this is possible), we come to mask the ways in which such a project always already fails (Ahenakew et al. 2014). If we believe we have narrated that which is un-narrativizable within the grammar of modernity, it becomes a differential (albeit subtler) act of subsuming, suturing over, or sublating Indigenous ways-of-knowing-in-being. But if we take Ahenakew's work (2017) seriously, this should not be an unanticipated consequence but rather par for the course: "modern academic literacies and technologies can make what has been made invisible by colonialism visibly absent, but they cannot make it present" (Ahenakew 2017, p. 89). In turn, there is a need to refuse and resist these metaphysics "without rejecting modernity wholesale" (Ahenakew et al. 2014 , p. 221, emphasis in original). In other words, the task of counter-hegemony must account for and be accountable to the ways in which the metaphysics of modernity always come to bear in the multiplicity of stages of research methodology from design to dissemination.

On questions of (re)presentation, Ahenakew states:

For those of us writing within academia, the first small step we need to take is to make grafting visible. Making grafting visible means writing in a way that makes what is invisible noticeably absent so that it can be remembered and missed. (Ahenakew 2016, p. 333)

\section{Amy Kim - An act of braiding with Nisitohtamowin and Kemochly}

Following the understanding that we are all related (and that the notion of we encompasses both living and non-living things) (Cajete 2000) and Nisitohtamowin (self-in-relation), I recognized that I needed to build relationship with all my data. Fairclough's three-tiered model assisted me in inviting and further building relationship with data. Recognizing that we are all related, I chose to approach to my relation with my data as an invitation rather than mere transaction, which required constant reflection throughout the research process. Therefore, I invited curriculum documents for the textual level; stories from different educational stakeholders (whom I refer to as sharers) for the discursive level; and the history and policies related to Indigenous education and science education for the social level (Figure 1).

Once I had all the data in front of me, I had to rebuild a relationship with the data. I first sat down with all the data and asked for my next steps. In this way, I engaged in the practice of "critical reflexivity" within the research process. I hoped to ensure that I did not miss, because of my assumptions and biases, any important aspects that would guide me in the analytic process. I also 
engaged in this process to follow the lesson I received from Tim O'Loan, a Truth and Reconciliation Commission (TRC) advisor from the Dene Nation. In regards to my project and my life, Tim told me, "Don't rush yourself. Allow your natural cadence. Remember three things: your journey, your God, and your cadence" (personal communication, January 30, 2017). Tim also advised me to break barriers, not only systemic barriers, but personal barriers. Thinking about what personal barriers may be affecting my research process encouraged me to slow down. Thus, instead of jumping into the next stage of the project, I paused for reflection and I decided to listen to the stories that were shared with me through the data collection process.

Indeed, reflecting with/from the stories shared by the sharers offered great advice in regards to my next steps in the research. Some stories guided me in my process of curriculum document analysis by giving suggestions such as focusing on topics within science education. Some stories introduced me to other works in the field of Indigenous education that I drew upon for my analytic process. Some stories offered wisdom and lessons about the protocol, which helped me strengthen other relationships in my life.

Once I engaged with stories from all my sharers, I analyzed the K-12 curriculum documents for the first time focusing on the specific topics and ideas covered in each grade. Meanwhile, I explored the histories of science education and Indigenous education in Canada. After, I went back to analyze the curriculum documents for the second time, focusing on Indigenous knowledges related content found within the documents. I re-visited the stories from the sharers and historical and political contexts I explored earlier.

This analytic process required that I move back and forth between data. Throughout the process, I found that while the data collection process was about me inviting each data into the project and making relationships with each data separately, the analysis process for me was about having dinner with all the data together. Data and I were sitting in a sharing place. Sometimes data would speak to me or sometimes data would converse with each other. In this light, I found my project was, in a way, finding its own course, rather than me leading the project. As I was part of the relations of all the data and the process, there were times that I waited with the mindset of Kemochly for data to speak and build relationships with each other.

\section{Thread 4: Methodological productions and reflections: Carrying the braid forward}

\section{Marc Higgins - (At)Tending to the graft: Looking forward by making visibly absent rather than the absent visible}

Perhaps, as Ahenakew (2017) states "we cannot read, write, think, philosophize, empirically analyze, interpret, or shout our way out of onto-epistemic hegemony" (p. 89); there is a need to (at)tend to the graft. Here the word play is productive, because not only does Ahenakew invite us to attend to the ways in which grafting becomes a site in which (neo-)coloniality plays out, but also signals the ways in which there is simultaneously a tendency towards these dynamics as well. Importantly, this impossibility is not to be off the hook (as what becomes possible when we strive towards the impossible?). Rather, it is a call to be cognizant of "the utilitarian risk to all-too-quickly instrumentalize and embrace Indigenous research methodologies as quick-fix solutions to or escapes from deep-rooted and ongoing (neo)colonial thinking" (Ahenakew 2016, p. 323).

Towards these ends, Ahenakew (2016) offers three methodological suggestions:

1) making grafting visible by highlighting the absences of our modes of inquiry and learning how to write tentatively about our data and findings, (2) using metaphor and poetry to disrupt sense-making and prompt sense-sensing in the experience of readers, and (3) turning our attention to and historicizing the 
referents that circumscribe Western frameworks of reasoning so we can recognize these referents in our researcher-selves and in our writing. (p. 337)

Returning to the question posed in the previous thread, what would it mean to highlight the absences seemingly 'lost' in translation? By this, I mean the absences that could be made intelligible through the methodological framework that was at play (e.g., visual stories of place were not through Indigenous languages or practices of places, only informed by them), as well as that which could not be made intelligible through them. One of the most notable non-narrativizable absence I continue encountering is that of spirituality (e.g., Higgins 2016). Spirituality presents a complicated and complex interfacing given the ways in which IWLN and spirituality cannot be disentangled while metaphysics (other than the naturalized and normative Cartesian metaphysics) are often defined as Nature's abject other within spaces of science and science education (see Cajete 1994). The absence generates complications for decolonizing science education: given Western modernity's ongoing and complex relationship with religion (and WMS' relationship to the metaphysics beyond Cartesian conceptions of Nature), spirituality often becomes a contested and complicated cultural interface that often results in the dialectic negation of Indigeneity (see Apffel-Marglin 2011).

I end this braiding with further questions. Not only because I have not arrived at firm sense of where I am going next in my methodological work, but also because such ontological indeterminacy is productive. Further, when epistemic ignorance makes it such that you cannot know what you do not know because of what you already know it is important to recognize that this important work does not happen outside of relation (as relation precedes methodological responsibility and shapes the ability to respond; see Higgins 2017b). So, yet again, I turn here to Ahenakew:

Can we desire things that harm the land and other people and enact a commitment to respecting all relations? How can we be sure that when we are listening to the land we are really listening, rather than enacting our own anthropomorphized and overcoded scripts about what we think it might be saying? Is centering Indigenous understandings of land the same thing as centering the land itself? How can we ensure that we respect the special relationship Indigenous peoples have to the land while also recognizing that all peoples live in relation to it (whether or not they recognize it), and without reifying stereotypes about the "Ecological Indian"? How can we recognize our own complicity in wounding the land and ourselves, in the past, the present and generations to come? How can we make more time to think and ask about the contradictory effects of our varied, conflicting desires and contradictory institutional demands? (Ahenakew 2017, p. 87)

Amy Kim - Reflection on decolonization in relation to self: Coming back to the beginning of the circle Methodological patch-working is always in process. Thomas and Green (2007) used the Medicine wheel to describe the learning process:

once you have journeyed around the wheel, you have the opportunity to learn from your experiences and journey around the wheel again, this time learning from your mistakes [...] if we remember what the challenges were in our previous journey, then our next journey can be different and more effective (p.92).

Kovach (2009) states that a way for non-Indigenous academics to support Indigenous scholarship is to decolonize self and institution. Meanwhile, Smith (1999) explains that decolonization in research practices is "a process which engages with imperialism and colonialism at multiple levels" (p. 21). One of the goals of a decolonizing agenda within research starts from self: this involves critically reflecting on oneself to resist the imperialism rooted in Western research practices (Smith 1999). Indeed, because the "personal is political" (Kovach 2009, p. 83), to participate in decolonization in any research 
project I undertake, I must begin by acknowledging Canada's colonial history along with examining my own history, beliefs and values about knowledge and how these in turn shape my research practice.

Donald (2009) uses the term colonial frontier logics to explain the "epistemological assumptions and presuppositions, derived from the colonial project of dividing the world according to racial and cultural categorizations" (p. 20). Colonial frontier logics are deeply embedded in the cultures of educational institutions and they make it possible to perpetuate the status quo between Indigenous knowledge and Western knowledge (i.e., Western Modern Science). Donald (2009) also describes the "exclusionary colonial practices [that] are still replicated and perpetuated" (p. 18) through colonial frontier logics, ensuring that Indigenous epistemologies and knowledges are underrepresented or ignored in every state and education system (Battiste and Henderson 2008). Among other factors, Kovach (2009) suggests that a decolonizing institutional agenda should be about examining the powers at play in institutions. In addition to these considerations, non-Indigenous researchers should listen and make space for Indigenous people's voices, rather than taking a stance as experts who speak on behalf of Indigenous peoples. Most importantly, as Wiseman mentioned, such exchanges should be about "making room [so] that we [both Indigenous and non-Indigenous] are learning together and in living together" (Personal communication, August 25, 2016)-a practice that can help to diminish the "divisiveness" between Indigenous and non-Indigenous people enforced by colonial frontier logics (Donald 2009). Meanwhile, Dr. Glen Aikenhead, a non-Indigenous scholar in the field of Indigenous science education, described decolonization as a process:

Decolonization is the other side of the coin of the post-colonial [where] the postcolonial means that you are not past being colonized. It means you recognize the ways in which neo-colonialism continues and you work at diminishing it, and even trying to eliminate it. And you are never going to get there... It [decolonization]'s a process; it is not a product (personal communication, March, 24 ${ }^{\text {th }}, 2016$ ).

Drawing from these conversations around decolonization, I conceptualize decolonization as a multilayered process, which involves self, institutions, nations, and the globe. However, in order for us to get there, we all need to work together to ensure that Indigenous peoples' voices are heard and valued in different political and social venues. As an individual in the process of becoming an ally, my decolonizing agenda for this research is therefore to examine my biases and assumptions first, and then to investigate power dynamics in educational institutions. In this way, I contribute to making space for Indigenous and non-Indigenous people to share and learn together. In so doing, I have committed to actively listening to and respecting the stories of Indigenous peoples. I have also committed to engaging in an open-learning process. I acknowledge that decolonization is an ongoing process, involving continuous learning experiences and building relationships. I thus continue in this process of learning, pondering theories, ideas, and conversations as they come into my living inquiry with the mindset of Nisitohtamowin and Kemochly.

\section{Conclusion: An open-ended invitation}

The decolonizing call remains as an ongoing critique of academic attempts to redefine, appropriate, command and authorize legitimate knowledge and methodologies. The motif of the native Other as an object of study has shaped most social science methodologies; it has helped define the very sense of objectivity. (Smith et al. 2016, p. 142)

Following after McMahon, Griese, and Baete Kenyon's manuscript that highlights the importance of drawing from and centering Indigenous pedagogical models, we bring attention to another educational space in which taking Indigenous thought seriously proves productive and significant: research 
methodology. As Smith and colleagues (2016) state above, most social science methodologies always already have a relationship to Indigeneity, albeit a problematic one in which processes of knowledge production (re)produce Indigenous bodies and ways-of-knowing-in-being as abject otherness against which Western modernity is normalized and naturalized. In turn, we view de/colonizing methodologies as not simply a task of incorporating Indigenous ways-of-knowing-in-being, but also attending to the complex and ongoing inter- and intra-cultural forces and flows within and between Indigenous and Western knowledge systems. The latter is of particular importance in a field in which a decolonizing imaginary might prove at very least challenging, if not impossible at this current juncture.

However, it is important to persist in re(con)figuring the possible possibilities as we labour towards the seemingly impossible. Thankfully, because "methodological fabric is also a fabrication" (Higgins et. al 2017, p. 17) in which theory, practice, and ethics are (en)tangled together, it is always open to being conceptualized and enacted anew. As Smith (1999) mentions,

the methodologies and methods of research, the theories that inform them, the questions which they generate and the writing styles they employ, all become significant acts which need to be considered carefully and critically before being applied. In other words, they need to be 'decolonized' (p. 41).

It is important to remember that the criticality signalled in the "decolonizing call as an ongoing critique" (Smith et al. 2016 p. 142) is always more than simply the process of dialectic negation; the work of de/colonizing methodologies is at once critical and creative. The work of de/colonizing methodologies can be done by strategically braiding in new strands that disrupt, displace, and disperse the (neo-)colonial logics that work to separate and make separable Indigenous-non-Indigenous relations. Braiding also makes visible the ways in which Western modernity comes to be reconstituted as dominant, as well as the multiplicity of material-semiotic practices that reinforce these. Within this manuscript, we take up and narrate this work differentially; however, given the pervasiveness and multiplicity of (neo-)colonial logics, difference here becomes a strength rather than a liability. With Ahenakew's (2016) concept of grafting, Marc Higgins responded to the call to not make visible that which is absent but rather make visible its absence so that it can be missed and remembered as the attempt to narrativize the un-narrativizable (within the grammar of modernity) only traps us in positions where we think we have represented but rather we have lost things in translation. With the Cree guiding principles, Nisitohtamowin and Kemochly, Eun-Ji Amy Kim was able to re-think her relationships with data sources and peoples that I encountered throughout the process. If one commits to a 'decolonizing' agenda in their research projects, one must engage in continuous "looking back behind the history" (Dr. Laara Fitznor, March, 26, 2016, personal communication) and building relationships while braiding multiple ways of knowing and doing research.

We end this manuscript with an invitation rather than an injunction to account for and be accountable to the ways that (neo-)colonial logics are always already at play within the methodological entanglement of theory-practice-ethics. We invite attention to the ways in which colonial logics interand intra-act with Indigenous ways-of-knowing-in-being. As de/colonizing methodologies are neither prescriptive nor prohibitive, it is in invitation to do so from one's own social, cultural, and material location with/in relations and commitments, as well as gifts that we and our participants have in order to honour the learning spirit in us all. "The intellectual work to decolonize methodologies continues" (Smith et. al 2016, p. 142); this work is never fully over.

\section{References}

Ahenakew, C. (2016). Grafting Indigenous ways of knowing onto non-Indigenous ways of being. International Review of Qualitative Research, 9(3), 323-340. 
Ahenakew, C. R. (2017). Mapping and complicating conversations about Indigenous education. Diaspora, Indigenous, and Minority Education, 11(2), 80-91.Ahenakew (2017

Ahenakew, C., Andreotti, V., Cooper, G., \& Hireme, H. (2014). Beyond epistemic provincialism: Deprovincializing Indigenous resistance. Alter-Natives: An International Journal of Indigenous Peoples, 10(3), 216-231.

Aikenhead, G.S., \& Michell, H. (2011). Bridging cultures: Indigenous and scientific ways of knowing nature. Toronto, ON: Pearson Canada Inc.

Andreotti, V., Ahenakew, C., \& Cooper, G. (2011). Epistemological pluralism: Ethical and pedagogical challenges in higher education. AlterNative: An International Journal of Indigenous Peoples, $7(1), 40-50$.

Apffel-Marglin, F. (2011). Subversive spiritualities: How rituals enact the world. New York: Oxford University Press.

Bang, M., \& Marin, A. (2015). Nature-culture constructs in science learning: Human/non-human agency and intentionality. Journal of Research in Science Teaching, 52(4), 530-544.

Barad, K. (2000). Reconceiving scientific literacy as agential literacy. In R. Reed and S. Traweek (Eds.), Doing Science+Culture (pp. 221-258). New York, NY: Routledge.

Battiste, M., \& Henderson, J. (2000). Protecting Indigenous knowledge and heritage. Saskatoon, SK: Purich.

Bishop, A. (2015). Becoming an ally: Breaking the cycle of oppression in people. Winnipeg, MB: Fernwood Publishing.

Cajete, G. (1994). Look to the mountain: An ecology of indigenous education. Durango, CO: Kivaki Press.

Cajete, G. (2000). Native science: Natural laws of interdependence. Santa Fe, NM: Clear Light Books. Canadian Association of University Teachers (2016). CAUT guide to acknowledging traditional territory. Retrieved from: https://www.caut.ca/docs/default-source/professional-advice/list---territorialacknowledgement-by-province.pdf?sfvrsn=12

Carter, L. (2005). A place for alternative readings: Can they be of use? Responding to comments on "Thinking differently about cultural diversity: Using postcolonial theory to (re)read science education." Science Education, 89(6), 913 -919.

Donald, D. (2009). Forts, curriculum, and Indigenous Métissage: Imagining decolonization of AboriginalCanadian relations in educational contexts. First Nations Perspectives, 2(1), 1-24.

Donald, D. (2012). Indigenous Métissage: A decolonizing research sensibility. International Journal of Qualitative Studies in Education, 25(5), 533-555.

Fairclough, N. (1989). Language and Power. Edinburgh gate, Harlow: Addison Wesley Longman Limited.

Fairclough, N. (1992). Discourse and social change. Maiden, MA: Polity Press.

Foucault, M. (1982). The subject and power. Critical Inquiry, 8(4), 777-795.

Grande, S. (2008). Red pedagogy: The un-methodology. In N.K. Denzin, Y.S. Lincoln, \& L.T. Smith (Eds.), Handbook of critical and Indigenous methodologies (pp. 225-254). London, UK: SAGE Publications.

Graveline, F. J. (1998). Circle works: Transforming Eurocentric Consciousness. Halifax, NS: Fernwood Publishing.

Higgins, M. (2014a). De/colonizing pedagogy and pedagogue: Science education through participatory and reflexive videography. Canadian Journal of Science, Mathematics and Technology Education, 14(2), 154-171.

Higgins, M. (2014b). Rebraiding photovoice: Putting to work Indigenous conceptions of praxis and standpoint theory. Australian Journal of Indigenous Education, 43(2), 208-217. 
Higgins, M. (2016). Decolonizing school science: Pedagogically enacting agential literacy and ecologies of relationships. In C. Taylor \& C. Hughes (Eds.), Posthuman Research Practices (pp. 267-289). Basingstoke, UK: Palgrave Macmillan.

Higgins, M. (2017a). Reconfiguring the optics of the critical gaze in science education (after the critique of critique): (Re)thinking "what counts" through Foucaultian prismatics. Cultural Studies in Science Education. DOI: 10.1007/s11422-016-9799-4

Higgins, M. (2017b). Post-qualitative mo(ve)ments: Concluding remarks on methodological response-abilities and being wounded by thought. Reconceptualizing Educational Research Methodology, 8(3), 89-101.

Higgins, M. (in press). Positing an(other) ontology within science education: Towards different practices of ethical accountability within multicultural science education. In K. Scantlebury \& C. Milne (Eds.), Material Practice and Materiality: Too Long Ignored in Science Education. New York: Springer.

Higgins, M., Madden, B., Bérard, M.-F., Lenz Kothe, E., \& Nordstrom, S. (2017). De/signing research in education: Patchwork(ing) methodologies with theory. Educational Studies, 43(1), 16-39.

Jackson, A. Y., \& Mazzei, L. A. (2012). Thinking with theory in qualitative research: Viewing data across multiple perspectives. New York, NY: Routledge.

Kovach, M. (2009). Indigenous methodologies: Characteristics, conversations and contexts. Toronto, ON: University of Toronto Press.

Lemke, J. (2011). The secret identity of science education: masculine and politically conservative?. Cultural Studies of Science Education, 6(2), 287-292.

McKinley, E. \& Aikenhead, G. (2005). Comments on "Thinking differently about cultural diversity: Using postcolonial theory to (re)read science education." Science Education, 89(6), 901-906.

McKinley, E. \& Stewart, G. (2012). Out of place: Indigenous knowledge in the science curriculum. In B. Fraser, K. Tobin, \& C. J. McRobbie (Eds.), Second international handbook of science education (pp. 541-554). Dordrecht, NL: Springer Netherlands.

Nakata, M. (2007). Disciplining the savages: Savaging the disciplines. Exploring inscriptions of Islanders in Western systems of thought. Canberra, Australia: Aboriginal Studies Press.

Sammel, A. (2009). Turning the focus from 'other' to science education: Exploring the invisibility of whiteness. Cultural Studies of Science Education, 4, 649-656.

Smith, L. T. (1999). Decolonizing methodologies: Research and Indigenous peoples. London, England: Zed Books.

Smith, L. T., Maxwell, T. K., Puke, H., \& Temara, P. (2016). Indigenous knowledge, methodology and mayhem: What is the role of methodology in producing Indigenous insights? A discussion from mātauranga Māori. Knowledge Cultures, 4(3), 131-156.

Spivak, G. C. (1976). Translator's preface. In J. Derrida, Of grammatology (G. C. Spivak, Trans.) (pp. ixIxxxvii). Baltimore, MD: Johns Hopkins University Press.

Spivak, G. C. (1999). A critique of postcolonial reason. Cambridge, MA: Harvard University Press.

TallBear, K. (2013). Native American DNA: Tribal belonging and the false promise of genetic science. University of Minnesota Press.

Thomas, R., \& Green, J. (2007). A way of life: Indigenous perspectives on anti-oppressive living. First Peoples Child and Family Review, 3(1), 91-104.

Tuck, E. (2009). Suspending damage: A letter to communities. Harvard Educational Review, 79(3), 409-428.

Wilson, S. (2008). Research is ceremony: Indigenous research methods. Halifax, NS: Fernwood Publishing. 
